The University of Southern Mississippi

The Aquila Digital Community

Faculty Publications

$1-1-2012$

\title{
Anticancer Activity and Biophysical Reactivity of Copper Complexes of 2-(benzo[d][1,3]dioxol-5-ylmethylene)-N- Alkylhydrazinecarbothioamides
}

\author{
Floyd A. Beckford \\ Lyon College, floyd.beckford@lyon.edu \\ Jeffrey Thessing \\ Lyon College \\ Alyssa Stott \\ Lyon College \\ Alvin A. Holder \\ University of Southern Mississippi, aholder@odu.edu \\ Oleg G. Poluektov \\ Argonne National Laboratory
}

See next page for additional authors

Follow this and additional works at: https://aquila.usm.edu/fac_pubs

Part of the Chemistry Commons

\section{Recommended Citation}

Beckford, F. A., Thessing, J., Stott, A., Holder, A. A., Poluektov, O. G., Li, L., Seeram, N. P. (2012). Anticancer Activity and Biophysical Reactivity of Copper Complexes of 2-(benzo[d][1,3]dioxol-5-ylmethylene)-NAlkylhydrazinecarbothioamides. Inorganic Chemistry Communications, 15, 225-229.

Available at: https://aquila.usm.edu/fac_pubs/8865

This Article is brought to you for free and open access by The Aquila Digital Community. It has been accepted for inclusion in Faculty Publications by an authorized administrator of The Aquila Digital Community. For more information, please contact Joshua.Cromwell@usm.edu. 


\section{Authors}

Floyd A. Beckford, Jeffrey Thessing, Alyssa Stott, Alvin A. Holder, Oleg G. Poluektov, Liya Li, and Navindra P. Seeram 


\title{
Anticancer activity and biophysical reactivity of copper complexes of 2-(benzo[d][1,3]dioxol-5-ylmethylene)- $\mathrm{N}$ - alkylhydrazinecarbothioamides
}

\author{
Floyd A. Beckford ${ }^{a},{ }^{,}$, Jeffrey Thessing ${ }^{a}$, Alyssa Stott ${ }^{a}$, Alvin A. Holder ${ }^{b}$, Oleg G. \\ Poluektov $^{\mathrm{C}}$, Liya Li ${ }^{\mathrm{d}}$, and Navindra P. Seeram. ${ }^{\mathrm{d}}$ \\ Floyd A. Beckford: floyd.beckford@lyon.edu \\ aScience Division, Lyon College, Batesville, AR 72501, USA \\ ${ }^{b}$ Department of Chemistry and Biochemistry, The University of Southern Mississippi, 118 College \\ Drive, \# 5043, Hattiesburg, Mississippi 39406, USA \\ ${ }^{\mathrm{C}}$ Argonne National Laboratory, Chemical Sciences and Engineering Division, Argonne, IL 60439, \\ USA \\ ${ }^{\mathrm{d} B i o a c t i v e ~ B o t a n i c a l ~ R e s e a r c h ~ L a b o r a t o r y, ~ D e p a r t m e n t ~ o f ~ B i o m e d i c a l ~ a n d ~ P h a r m a c e u t i c a l ~}$ \\ Sciences, University of Rhode Island, RI 02881, USA
}

\begin{abstract}
A series of copper complexes were synthesized from benzo[d][1,3]dioxole-5-carbaldehyde (piperonal) thio-semicarbazones (RHpTSC where $\mathrm{R}=\mathrm{H}, \mathrm{CH} 3, \mathrm{C} 2 \mathrm{H} 5$ or $\mathrm{C} 6 \mathrm{H} 5(\mathrm{Ph})$ ). The complexes show interesting variations in geometry depending on the thiosemicarbazone; a dinuclear complex [Cu(HpTSC)Cl]2, a mononuclear complex [Cu(RHpTSC)2Cl2] (R=CH3 or $\mathrm{C} 2 \mathrm{H} 5)$ and another mononuclear complex $[\mathrm{Cu}(\mathrm{PhHpTSC})(\mathrm{PhpTSC}) \mathrm{Cl}]$ was generated. The complexes bind in a moderately strong fashion to DNA with binding constants on the order of $10^{4} \mathrm{M}^{-1}$. They are also strong binders of human serum albumin with binding constants near $10^{4}$ $\mathrm{M}^{-1}$. The complexes show good in vitro cytotoxic profiles against two human colon cancer cell lines (HCT-116 and HT29) and two human breast cancer cell lines (MCF-7 and MDA-MB-231) with IC50 values in the low millimolar concentration range.
\end{abstract}

\section{Keywords}

Human serum albumin; Thiosemicarbazones; Anticancer; DNA binding; Structural variation

\section{Introduction}

The synthesis and chemical investigations of thiosemicarbazones (TSCs) and their metal complexes are of considerable importance because of their potentially beneficial medicinal applications and a wide variation in their modes of bonding and stereochemistry [1-3]. The

(C) 2011 Elsevier B.V. All rights reserved.

*Corresponding author. Tel.: + 1870307 7212; fax: + 18703077496.

Appendix A. Supplementary material: Supplemenatary data to this article can be found online at doi:10.1016/j.inoche.2011.10.032.

Publisher's Disclaimer: This is a PDF file of an unedited manuscript that has been accepted for publication. As a service to our customers we are providing this early version of the manuscript. The manuscript will undergo copyediting, typesetting, and review of the resulting proof before it is published in its final citable form. Please note that during the production process errors may be discovered which could affect the content, and all legal disclaimers that apply to the journal pertain. 
biological activity of thiosemicarbazones is related to their chelating ability with transition metal ions. This chelating ability is a function of the unique characteristics of the mixed hard-soft NS donor atoms in the structure. The structure of TSCs offer up a variety of donor atom sets such that they are versatile ligands in both neutral and anionic forms. TSC ligands exist as thione-thiol tautomers (although the proton lost to form the anion formally belongs to the hydrazinic $-\mathrm{NH}$ group). The exploration of copper complexes as chemical nucleases is well documented because they possess biologically accessible redox potentials and relatively high nucleobase affinity. Copper(II) thiosemicarbazone complexes have been the focus of investigation as metallodrugs for various medical applications for a long period of time. These applications include use as anti-cancer drugs [3-6]. As with most drugs seeking to arrest the development of cancer, the cellular targets for copper complexes are not exactly defined and may be variegate. DNA is most certainly a possibility but the compounds are likely to encounter other biomolecules such as proteins either at or en route to the site of action. Consequently proteins in general would also be a distinct set of molecular targets. As the principal extracellular protein of the circulatory system, human serum albumin (HSA) serves as the major transporter of drugs as well as endogenous compounds [7]. It is well understood that the distribution, free concentration and the metabolism of various drugs can be significantly altered as a result of their binding to HSA. Since HSA serves as a transport carrier for drugs, it is important to study the interactions of potential drugs with this protein. Knowledge of interaction mechanisms between drugs and plasma proteins is of crucial importance to the understanding of the pharmacodynamics and pharmacokinetics of a drug or drug prospect.

\section{Discussion}

The experimental procedures are similar to those that we have reported [8]. The ligands were synthesized as previously reported [8]. The reaction of the ligands with copper(II) chloride produces complexes 1-4 as light yellow, or tan in the case of $\mathbf{4}$, solids (Scheme 1) (also see Supplemental Information). The complexes have been characterized by elemental analyses, conductimetry as well as ESR and infrared spectroscopy. Based primarily on elemental analysis and supported by infrared data, we have observed a variegate set of coordination geometries for the complexes based on the nature of the ligand. When the ligand has the amino nitrogen unsubstituted the complex (1) that is formed is best formulated as dimeric species in the solid state. The complex has two four-coordinate copper centers linked by two chloride bridges with the thiosemicarbazone coordinated as the anionic form.

The ESR spectra of the complexes (Fig. 1) were recorded at $43 \mathrm{~K}$ in DMSO, using a Bruker ELEXSYS 580 spectrometer. The spectra of the complexes reveal a lineshape that is typical for $\mathrm{Cu}^{2+}$ with axial symmetry of g-tensor. Theoretical fitting of the spectra gives the following magnetic resonance parameters; g-tensor: $\mathrm{g}=2.08276$; and $\mathrm{g}=2.4140$; hyperfine interaction tensor with $\mathrm{Cu}$ nucleus ( $\mathrm{I}=3 / 2): \mathrm{A}=1.1 \cdot 10^{-2} \mathrm{~cm}^{-1} ; \mathrm{A}<10^{-3} \mathrm{~cm}^{-1}$; and hyperfine interaction tensor with two equivalent nitrogens ( $\mathrm{I}=1)$ : $\mathrm{A}=1.3 \cdot 10^{-3} \mathrm{~cm}^{-1} ; \mathrm{A}<10^{-3} \mathrm{~cm}^{-1}$. ESR data suggest that in DMSO solutions these complexes, including 1, are mononuclear species in nature. This behavior is not unprecedented in copper thiosemicarbazone chemistry. Krishna et. al. [9] observed a similar phenomenon in their study of binuclear copper complexes of cuminaldehyde thiosemicarbazones.

The conductivity of millimolar solutions of 1 was $4.3 \Omega^{-1} \mathrm{~cm}^{2} \mathrm{~mol}^{-1}$. This indicates the non-electrolyte nature of this complex [10]. When the amino nitrogen is substituted with a methyl (2) or ethyl (3) group the expected stoichiometry of the compound is observed. Once more, conductivity values for the two complexes $\left(2.81 \Omega^{-1} \mathrm{~cm}^{2} \mathrm{~mol}^{-1}\right.$ for 2 and $3.15 \Omega^{-1}$ $\mathrm{cm}^{2} \mathrm{~mol}^{-1}$ for 3 ) are such that the octahedral formulation with both chlorides present in the 
coordination sphere is justified. Complex 4 with the phenyl-substituted amino nitrogen provides the most curious coordination mode. We mentioned before that thiosemicarbazones can undergo tautomerization and subsequent deprotonation of the thiol form allowing for a mono-anionic ligand. We are proposing that in complex $\mathbf{4}$ both types of binding - neutral and anionic - are present. The result is a five-coordinate (likely square pyramidal) copper center. This proposal is based primarily on micro-analytical data (though the infrared data lend some support). There is literature precedence for this type of mixed-mode binding. Joseph [11] have suggested that copper(II) can complex 2-benzoylpyridine N(4)-phenyl thiosemicarbazone in such a fashion although in their case one ligand is tridentate bearing the anionic form and the other is a monodentate binder using the iminic nitrogen. Souza [12] has reported that in the platinum complexes of 3,5-diacety1-1,2,4-triazol bis(thiosemicarbazones) one arm of the ligand coordinates as the neutral thione form and the other arm as the deprotonated thiol form.

Thiosemicarbazones exhibit characteristic bands corresponding to various groups in specific energy regions. Infrared spectrophotometry can be used to identify the coordinated form and it was observed that the characteristic absorption peaks of all complexes are similar (Table 1). The presence of a band corresponding to $\mathrm{N}-\mathrm{H}$ group (the azomethinic nitrogen), suggests the coordination of a thiosemicarbazone to the metal center in a neutral form, while its absence, would be suggestive of deprotonation of the azomethinic proton in the complexes. For $\mathbf{1}$, one would expect six bands (or three for exact symmetric geometry) in the $\mathrm{NH}$ region for the $\mathrm{NH}_{2}$ and $\mathrm{NH}$ hydrogens. The presence of the four corresponding to the terminal $\mathrm{NH}_{2}$ supports the formulation of the complexed ligands as the anionic form. The presence of these bands in $\mathbf{2}$ and $\mathbf{3}$ supports the thione formulation of the ligand in those complexes and they do not shift significantly on complexation. For complex 4 the presence of three rather than two bands in this region and particularly the absence of the lower energy band lend support to the idea that there are two forms of the thiosemicarbazone ligand coordinated to the metal. The coordination sites can also be inferred the spectral bands attributed to the $\mathrm{C}=\mathrm{N}$ iminic and $\mathrm{C}=\mathrm{S}$ thioamide IV groups. The ligands show a medium intensity band at $1570-1600 \mathrm{~cm}^{-1}$ that we ascribe to $\mathrm{C}=\mathrm{N}$ and these are generally shifted to lower energy upon complexation. The involvement of the thiocarbonyl group can similarly be inferred from the wavenumber shifts that occur on binding.

The redox behavior of the complexes has been studied by cyclic voltammetry at a platinum disc electrode in $1 \times 10^{-3} \mathrm{M}$ dichloromethane solutions containing $0.1 \mathrm{M}$ tetrabutylammonium hexafluorophosphate as the supporting electrolyte. The voltammograms for the compounds are very similar. In the positive direction all the complexes show two irreversible anodic peaks; at $300 \mathrm{mV} / \mathrm{s}$ the first occurs at $+0.407 \mathrm{~V}$ for $\mathbf{1},+0.385 \mathrm{~V}$ for $\mathbf{2},+0.407 \mathrm{~V}$ for $\mathbf{3}$, and $+0.375 \mathrm{~V}$ for $\mathbf{4}$ all relative to $\mathrm{Ag} / \mathrm{AgCl}$. This couple is assumed to be the metal-based oxidation $\mathrm{Cu}(\mathrm{II}) / \mathrm{Cu}(\mathrm{III})$. While these values might appear low, other works have reported similar values and have suggested that the redox process associated with the oxidation of $\mathrm{Cu}$ (II) to $\mathrm{Cu}$ (III) may probably originate due to the presence of the thione sulfur center [13]. We have noted for other copper complexes in our labs (unpublished work) similar electrochemical behavior and it appears that the $\mathrm{Cu}(\mathrm{II}) / \mathrm{Cu}$ (III) redox couple can merge with the redox couple of the oxidized ligand around $+0.75 \mathrm{~V}$. We are also carrying out extensive square wave voltammetry in order to ascertain the separate redox couple for the ligand and the $\mathrm{Cu}(\mathrm{II}) / \mathrm{Cu}(\mathrm{III})$ redox process. The second peak is illdefined and occur at $+1.33 \mathrm{~V}$ for all the complexes except for $\mathbf{1}$ where it occur at $+1.44 \mathrm{~V}$. We are not exactly sure of the nature of this couple but based on the constancy of the potential we propose that it might be ligand based [13]. The single oxidation peak observed for complex 1 would appear to support the EPR data that it is monomeric in the solution phase. It should be noted that the lower scan rate $(100 \mathrm{mV} / \mathrm{s})$ the first peak is hardly noticeable but becomes more pronounced as the scan rate is increased. (See Supplemental 
Information). Cyclic voltammetric studies of thiosemicarbazone ligands have shown the existence of an irreversible cathodic peak at $-1.06 \mathrm{~V}$, assignable to the reduction of the thione group of the thiosemicarbazone moiety [13]. In our complexes this peak appears at $0.659 \mathrm{~V},-0.609 \mathrm{~V},-0.598 \mathrm{~V}$ and $-0.587 \mathrm{~V}$ for $1,2,3$ and 4 respectively.

\section{Ethidium bromide competition experiment}

We have investigated the reaction of the complexes with calf thymus DNA via a fluorescence competition experiment. Ethidium bromide (EB) is a well-known dye that is commonly used as a marker for nucleic acids by intercalating between the base pairs and generating a fluorescent adduct. The fluorescence from the adduct may be quenched by addition of a compound that can displace the EB from the binding sites on the DNA. This quenching may be taken as evidence that the compound can bind to DNA. Using $\mathbf{3}$ as a typical example, we can see from Fig. 2 that the complex can indeed reduce the fluorescence of the EB-DNA solution by as much as $63 \%$. A quantitative estimate of this quenching behavior can be obtained by treating the data according to the Stern--Volmer Eq. (1):

$$
\frac{\mathrm{F}_{0}}{\mathrm{~F}}=1+\mathrm{K}_{\mathrm{sv}}[\mathrm{Ru}]=1+\mathrm{K}_{\mathrm{q}} \tau_{0}[\mathrm{Ru}]
$$

In this equation $\mathrm{F}_{0}$ and $\mathrm{F}$ are the fluorescence intensities of the reaction solution in the absence and presence of the metal compound. $\mathrm{K}_{\mathrm{SV}}$ is the Stern-Volmer quenching constant which is the measure of the effectiveness of the complex as a quencher. The inset of Fig. 2 shows the Stern-Volmer plots and the linearity of the plots for $\mathbf{2}$ and $\mathbf{3}$ confirm the quenching behavior. The values of the quenching constant seen in Table 2 are on the order of $10^{4} \mathrm{M}^{-1}$ indicating that these are moderately strong quenchers. The Stern-Volmer plot for complex 1 shows a positive deviation from linearity at high concentrations of the complex. The quenching of the fluorescence can occur by two common mechanisms - dynamic and static quenching. The deviation from linearity is usually explained by suggesting that there are multiple binding sites on the fluorophore or that both quenching mechanisms are occurring simultaneously. The static contribution may be calculated from the following Eq. (2):

$$
\frac{\mathrm{F}_{0}}{\mathrm{~F}}=\left(1+\mathrm{K}_{\mathrm{D}}[\mathrm{Q}]\right)\left(1+\mathrm{K}_{\mathrm{S}}[\mathrm{Q}]\right)
$$

where $\mathrm{K}_{\mathrm{D}}$ and $\mathrm{K}_{\mathrm{S}}$ are the dynamic and static quenching constants. ( $\mathrm{K}_{\mathrm{S}}$ would actually represent the formation constant for a dark complex between the quencher and the chromophores). However a completely unambiguous assignment of $\mathrm{K}_{\mathrm{D}}$ and $\mathrm{K}_{\mathrm{S}}$ requires fluorescence lifetime measurements [14] (though varying temperature can be used to characterize the quenching as predominantly dynamic or static). We propose that for $\mathbf{1}$ the static contribution is significant. This is inferred from the bimolecular quenching constant ( $\mathrm{K}_{\mathrm{q}}$ in Eq. 1) calculated by using $\tau_{0}=22 \mathrm{~ns}$ [15] for the EB-DNA complex. $\mathrm{K}_{\mathrm{eq}}$ for the reactions are on the order of $10^{12} \mathrm{M}^{-1} \mathrm{~s}^{-1}$ which is two orders of magnitude larger than the limiting value of $10^{10} \mathrm{M}^{-1} \mathrm{~s}^{-1}$ [16] considered the largest possible value in aqueous solution.

To assess the strength of the binding Eq. 3 was employed to calculate the apparent binding constant. 


$$
\mathrm{K}_{\mathrm{app}}=\frac{\mathrm{K}_{\mathrm{EB}}[\mathrm{EB}]}{[\mathrm{Cu}]_{50 \%}}
$$

In this equation $\mathrm{K}_{\mathrm{EB}}$ is the binding constant for ethidium bromide, taken as $1.2 \times 10^{6} \mathrm{M}^{-1}$ [17], and $[\mathrm{Cu}]_{50 \%}$ is the concentration of the complex that causes a $50 \%$ reduction of the initial fluorescence. These values are shown in Table 2 and range from $1.79 \times 10^{4}$ to $2.23 \times$ $10^{4} \mathrm{M}^{-1}$ which suggest that the complexes are moderate to strong binders.

\section{Reaction of the complexes with HSA}

Human serum albumin (HSA) is the most abundant of the blood serum proteins occurring to the extent of $0.63 \mathrm{mM}$ [7]. The protein serves as a transport unit for a wide variety of endogenous substances including drugs. In this study we investigated the binding of the complexes to HSA using fluorescence spectroscopy. HSA has a well-known structure that contains a single tryptophan residue that is responsible for the majority of the intrinsic fluorescence of the protein. On excitation at $295 \mathrm{~nm}$ HSA has strong fluorescence emission at $350 \mathrm{~nm}$. This emission can be attenuated by a small molecule binding at or near the tryptophan as this amino acid unit is quite susceptible to changes in its environment. As a representative example Fig. 3a shows that addition of $\mathbf{2}$ to HSA can very efficiently reduce the fluorescence of the solution. Moreover the wavelength of maximum fluorescence increased to $369 \mathrm{~nm}$ from $344 \mathrm{~nm}$ after addition of $22.5 \mu \mathrm{M}$ of the complexes. It has been noted [18] that the polarity of the molecular environment around the tryptophan residue affects the wavelength of maximum fluorescence. So the $25 \mathrm{~nm}$ red shift is indicative of a change to a more hydrophilic environment around the tryptophan fluorophore on addition of the complexes. So we can conclude that the complexes in general can bind to HSA. We can obtain a quantitative estimate of the strength of this binding by treating the data using the Stern-Volmer equation (Eq. 1). Treatment of the data in this manner resulted in the plots shown in Fig. 3b. It was observed that the plots were not linear as predicted from the equation but showed significant positive deviations from linearity at higher concentration of added metal complexes. There are two common explanations for this deviation. First the HSA fluorescence can be quenched via both of the common quenching mechanism operating simultaneously. Alternatively there might be multiple independent binding sites on the HSA and they are not all accessible to the complexes. Under these circumstances, the binding constant for the reaction can be obtained from a modified Stern-Volmer (MSV) analysis. This involves treating the data using eq. 4 :

$$
\frac{\mathrm{F}_{0}}{\mathrm{~F}_{0}-\mathrm{F}}=\frac{1}{f \mathrm{~K}[\mathrm{Cu}]}+\frac{1}{f}
$$

Here $f=$ fraction of the fluorophore that is initially accessible to the complex which might be interpreted as the number of binding sites. $\mathrm{K}$ is the effective quenching constant for the fluorophore which can be taken as a binding constant assuming the decrease in fluorescence comes from the interaction of the HSA with the complexes. Fig. $3 \mathrm{C}$ shows the plot of $\mathrm{F}_{0} / \mathrm{F}_{0^{-}}$ $\mathrm{F}$ vs. $1 /[\mathrm{Cu}]$ from which we obtain $\mathrm{K}$ from the ratio of the intercept to the slope. The derived binding constants are between $10^{4}$ and $10^{5} \mathrm{M}^{-1}$ indicating that they are strong binders (Table 3).

\section{Cytotoxicity studies}

Compounds 1-4 were evaluated for their cytotoxicity against a panel of human tumor cell lines (MCF-7, MDA-MB-231, HCT116 and HT29) by means of a colorimetric (MTS) assay which measures mitochondrial dehydrogenase activity as an indication of cell viability [8]. 
The effects of the compounds on the viability of these cells were evaluated after an exposure period of $72 \mathrm{~h}$. Cisplatin was used as comparison. All the complexes showed activity and their corresponding $\mathrm{IC}_{50}$ values, corresponding to inhibition of cancer cell growth at the $50 \%$ level, are listed in Table 4 . All the complexes show good cytotoxic profiles, with $\mathrm{IC}_{50}$ values generally in the low micromolar concentration range. As a general observation, the monomeric octahedral complexes are more cytotoxic than either the dimeric or mixtautomer complexes. DNA is a major cellular target for metal complexes but given that there is no significant difference in the DNA binding constants of the complexes, that ability to bind DNA may not be an important reason for the difference in cytotoxicity. Between cell lines there are no discernible trends; the compounds showed similar activities against the MDA-MB-231 cells, which are estrogen receptor negative (ER(-)) and the ER(+) MCF-7 cells. There is a slightly more but still weakly defined trend present in the colon cell lines activity is higher in the HCT-116 cells. Considering the structural nature of the thiosemicarbazone moiety, there appears to be no effect of the alkyl substituent on the amine nitrogen on the cytotoxicity of the complexes. Another point to note is that under our assay conditions the cells are in general more sensitive to the complexes than to the cisplatin comparison.

\section{Supplementary Material}

Refer to Web version on PubMed Central for supplementary material.

\section{Acknowledgments}

The project described was supported by Award Number P20RR16460 from the National Center for Research Resources to FAB. The content is solely the responsibility of the authors and does not necessarily represent official views of the National Center for Research Resources or the National Institutes of Health. AAH is also grateful for the use of our EMX ${ }^{\text {micro }}$ ESR spectrometer, which was funded by the NSF CRIF:MU Award \# 0741991. AAH would like to note that this work was also supported in part by P20RR016476 (the Mississippi INBRE funded by the National Center for Research Resources/NIH).

\section{References}

1. (a) Bahr G, Anorg Z. Allg Chem. 1952; 268:351.Bahr G, Anorg Z. Allg Chem. 1953; 273:325.(b) Bahr G, Schleitzer E, Anorg Z. Allg Chem. 1955; 278:136.

2. Jones CJ, McCleverty JA. J Chem Soc A. 1970; 2829

3. (a) Petering, DH. Carcinostatic copper complexes. Sigel, H., editor. Marcel Dekker; New York: 1980. (b) West DX, Hall IH, Rajendran KG, Liberta AE. Anticancer Drugs. 1993; 4:231. [PubMed: 8490202]

4. (a) Padhye S, Kauffman SB. Coord Chem Rev. 1985; 63:127.(b) West DX, Liberta AE, Padhye SB, Chikate RC, Sonawane PB, Kumbhar AS, Yerande RG. Coord Chem Rev. 1993; 123:49.

5. Byrnes RW, Mohan M, Antholine WE, Xu RX, Petering DH. Biochemistry. 1990; 29:7046. [PubMed: 2171640]

6. (a) Afrasiabi Z, Sinn E, Padhye S, Dutta S, Padhye S, Newton C, Anson CE, Powell AK. J Inorg Biochem. 2003; 95:306. [PubMed: 12818801] (b) Matesanz AI, Perez JM, Navarro P, Moreno JM, Colacio E, Souza P. J Inorg Biochem. 1999; 76:29. [PubMed: 10530004]

7. Kragh-Hansen U, Chuang VTG, Otagiri M. Biol Pharm Bull. 2002; 25:695. [PubMed: 12081132]

8. (a) Beckford FA, Thessing J, Shaloski M Jr, Mbarushimana PC, Brock A, Didion J, Woods J, Gonzalez-Sarrías A, Seeram NP. J Mol Struct. 2011; 992:397.(b) Beckford FA, Shaloski M Jr, Thessing J, Woods J, Dourth D, Didion J, Gerasimchuk N, Gonzalez-Sarrías A, Seeram NP. J Inorg Biochem. 2011; 105:1019. [PubMed: 21666776]

9. Krishna PM, Reddy KH, Pandey JP, Siddavattam D. Transition Met Chem. 2008; 33:661.

10. Geary WJ. Coord Chem Rev. 1971; 7:81. 
11. Joseph M, Kuriakose M, Prathapachandra Kurup MR, Suresh E, Kishore A, Bhat SG. Polyhedron. 2006; 25:61.

12. Matesanz AI, Souza P. J Inorg Biochem. 2007; 101:24.

13. (a) Sonawane P, Kumbhar A, Padhye S, Butcher RJ. Transit Met Chem. 1994; 19:277-282.(b) Padhye S, Chikate R, Kumbhar A, Shallom JM, Chitnis MP. BioMetals. 1992; 5:67-71. [PubMed: 1525479] (c) Murugkar A, Padhye S, Guha-Roy S, Wagh U. Inorg Chem Commun. 1999; 2:545548.(d) Chikate RC, Belapure AR, Padhye SB, West DX. Polyhedron. 2005; 24:889-899.

14. Eftnik R, Ghiron CA. Anal Biochem. 1981; 44:199.

15. Ghosh KS, Sahoo BK, Jana D, Dasgupta S. J Inorg Biochem. 2008; 102:1711. [PubMed: 18541305]

16. Lacowicz, JR. Principles of Fluorescence Spectroscopy. 3rd. Springer; New York: 2006.

17. Peberdy JP, Malina J, Khalid S, Haman MJ, Rodger A. J Inorg Biochem. 2007; 101:1937. [PubMed: 17719088]

18. Kragh-Hansen U, Hellec F, de Forestra B, le Maire M, Møller JV. Biophys J. 2001; 80:289. 


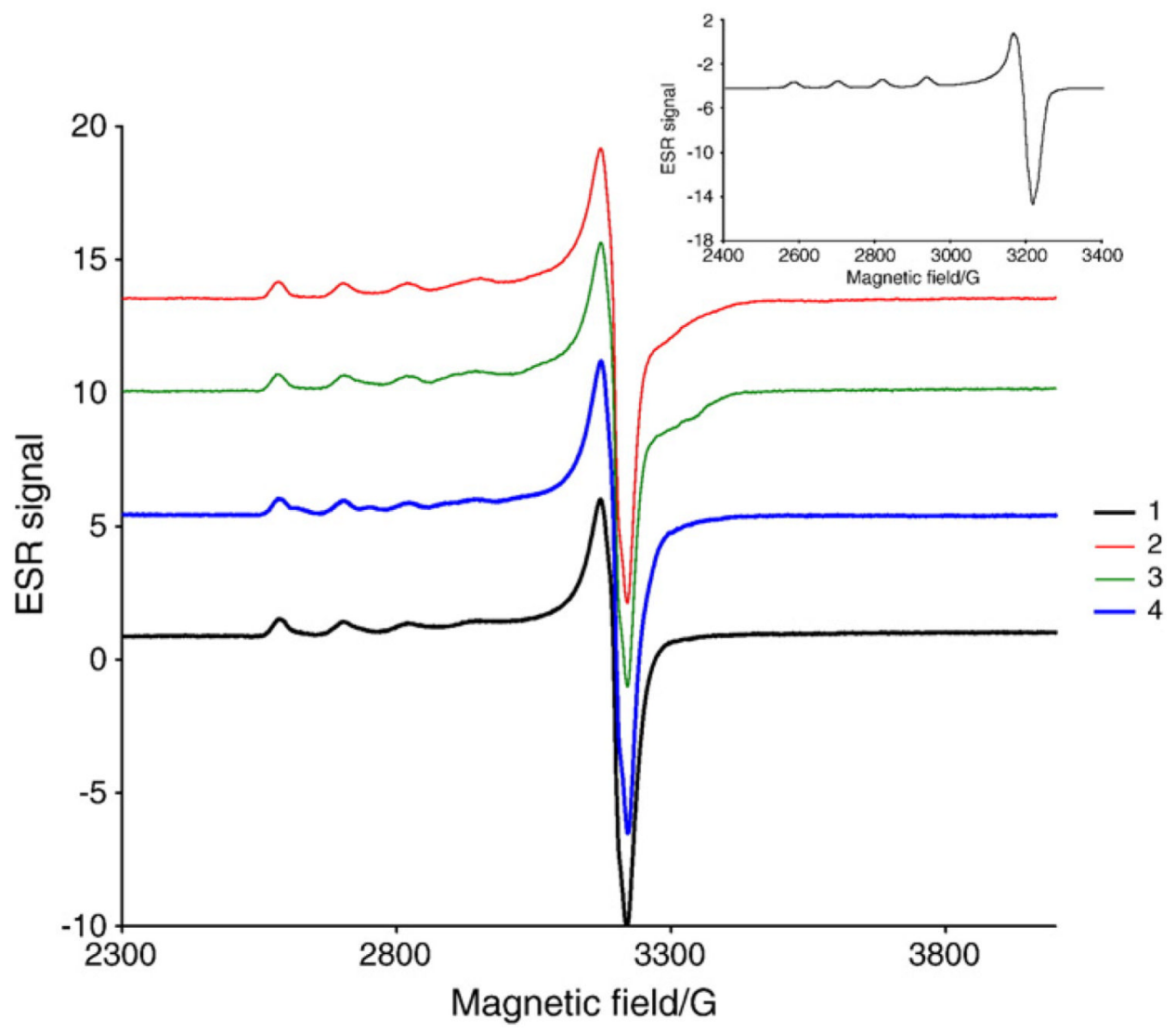

Fig. 1.

ESR spectra of compounds 1-4 in DMSO at $43 \mathrm{~K}$. Inset=simulation ESR spectrum. 


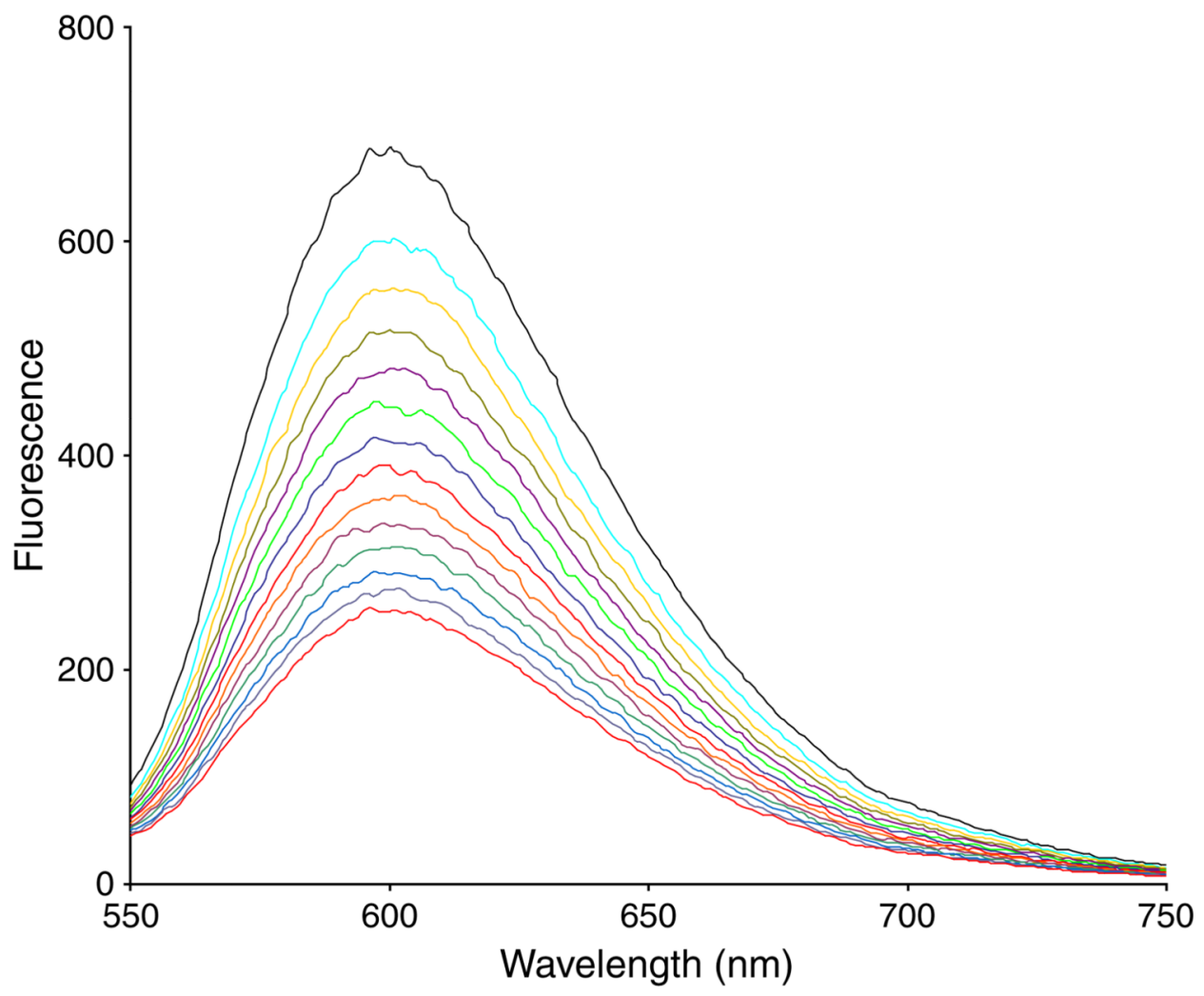

Fig. 2.

Fluorescence emission spectra of the EB-DNA adduct in the absence and presence of increasing amounts of $2, \lambda_{\mathrm{ex}}=520 \mathrm{~nm},[\mathrm{~EB}]=0.33 \mu \mathrm{M},[\mathrm{DNA}]=10 \mu \mathrm{M},[2](\mu \mathrm{M}): 0-32.5$ in $2.5 \mu \mathrm{M}$ increments. Temperature $=303 \mathrm{~K}$. Inset: Stern-Volmer plots for the complexes. 

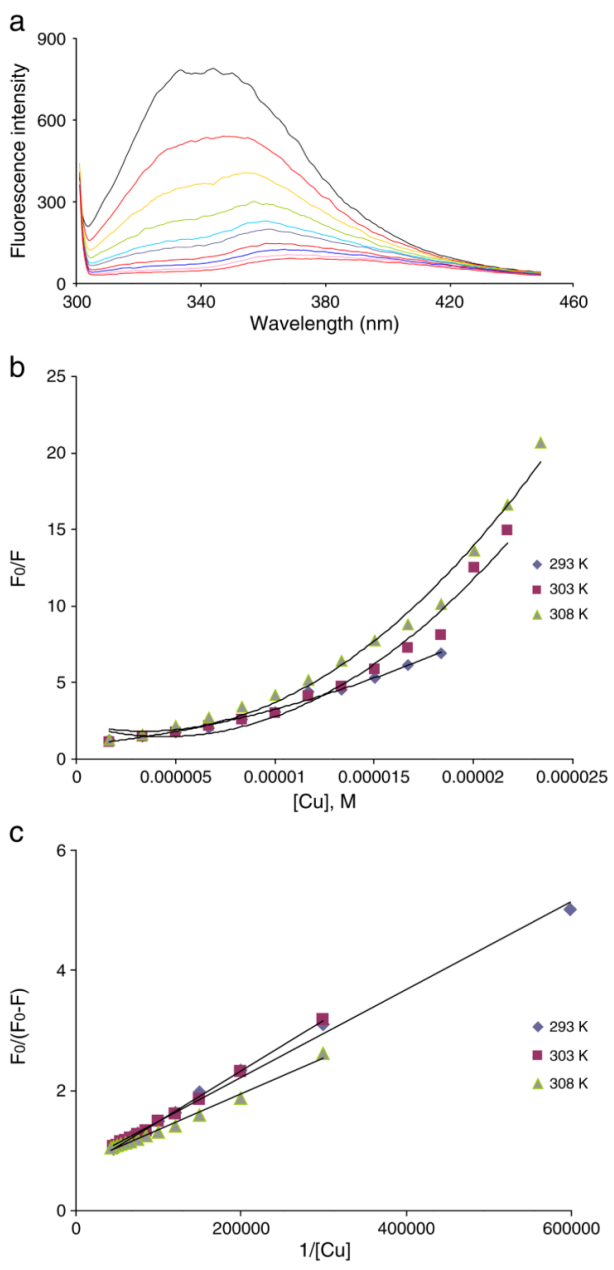

Fig. 3.

Reactions with HSA. (a) Fluorescence emission spectra of HSA in the absence and presence of increasing amounts of $2, \lambda_{\mathrm{ex}}=295 \mathrm{~nm},[\mathrm{HSA}]=5.0 \mu \mathrm{M}$ and [2] $(\mu \mathrm{M}): 0-22.5$ in $2.5 \mu \mathrm{M}$ increments. Temperature $=303.0 \mathrm{~K}$ (b) Stern-Volmer plots for the reaction of the complexes at $308 \mathrm{~K}$ (c) Plot of the modified Stern-Volmer equation: $\mathrm{F}_{0} /\left(\mathrm{F}_{0}-\mathrm{F}\right)$ vs. $1 /[\mathrm{Cu}]$, for the reaction of the complexes. 


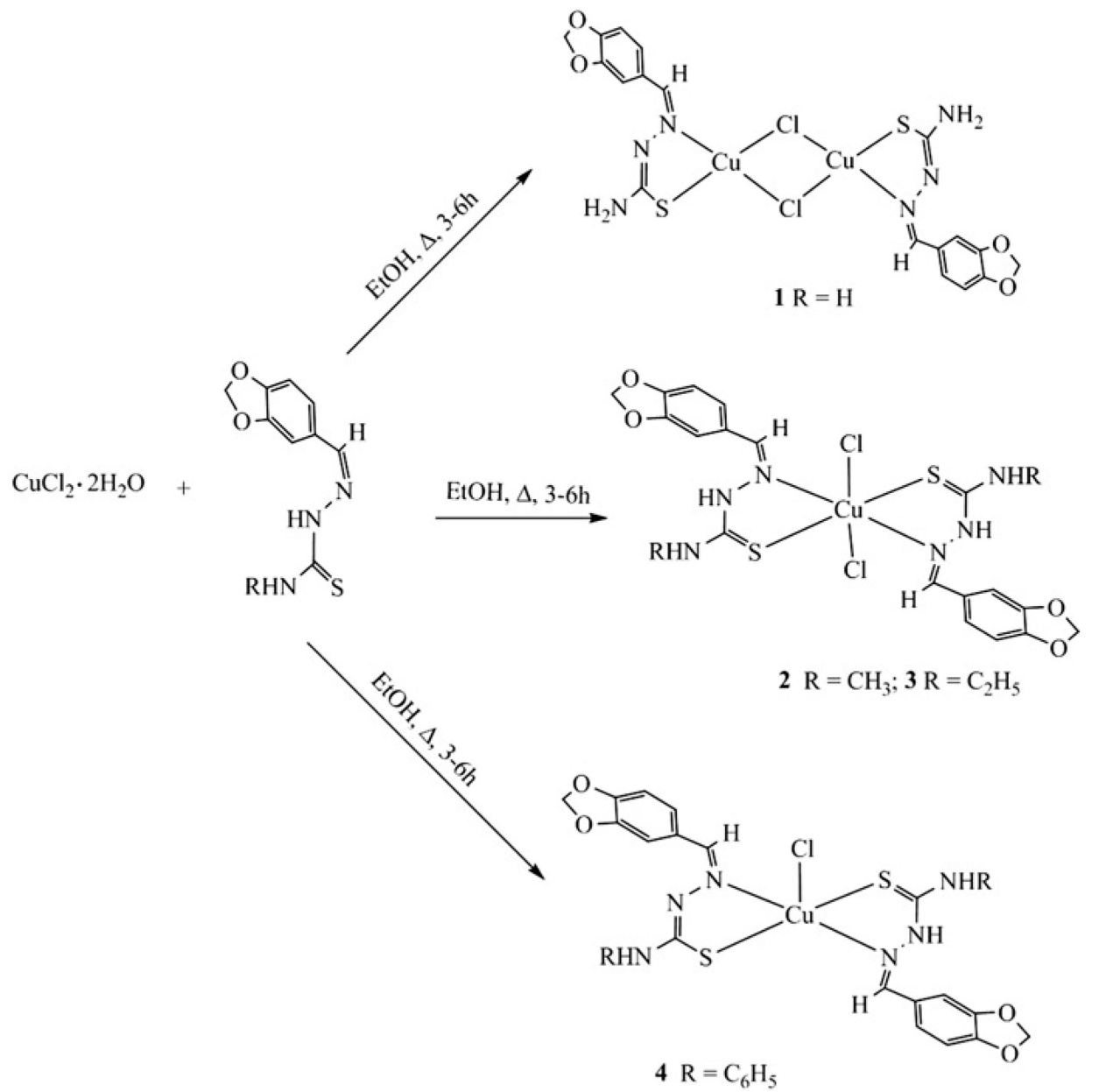

Scheme 1.

Proposed structures of the complexes prepared in this study. 
Table 1

Selected IR ${ }^{a}$ data for the complexes.

\begin{tabular}{|c|c|c|c|c|}
\hline \multirow[b]{2}{*}{ Assignment $b$} & \multicolumn{4}{|l|}{ Complex } \\
\hline & 1 & 2 & 3 & 4 \\
\hline$v_{N H}$ & $3415,3397,3236(w), 3129$ & $3389,3131(3339,3147)$ & $3366,3130(3373,3135)$ & $3331,3300,3086$ (b) $(3303,3134)$ \\
\hline$\nu_{\mathrm{C}=\mathrm{N}}$ & $1592(1589)$ & $1573(1590)$ & $1564(1589)$ & $1589(1596)$ \\
\hline$v_{\mathrm{C}=\mathrm{S}}$ & $1267,831(1290(w), 835)$ & $1257,839(1284,826)$ & $1280,830(1314,832)$ & $1330,851(1319,868)$ \\
\hline
\end{tabular}

$\mathrm{w}=$ weak, $\mathrm{b}=$ broad; values in parentheses are from the free ligands.

${ }^{a}$ (ATR).

$b_{\text {In cm }}-1$. 
Table 2

Binding constants for the interaction of the complexes with the EB-DNA adduct at $303 \mathrm{~K}$.

\begin{tabular}{lllll}
\hline & $\mathbf{1}$ & $\mathbf{2}$ & $\mathbf{3}$ & $\mathbf{4}$ \\
\hline $10^{4} \mathrm{~K}_{\mathrm{SV}}\left(\mathrm{M}^{-1}\right)$ & - & 5.35 & 4.26 & 0.773 \\
$10^{4} \mathrm{~K}_{\mathrm{app}}\left(\mathrm{M}^{-1}\right)$ & 2.23 & 1.79 & 1.91 & 0.406 \\
$10^{4} \mathrm{~K}_{\mathrm{q}}\left(\mathrm{M}^{-1} \mathrm{~s}^{-1}\right)$ & - & 2.43 & 1.94 & 0.351 \\
\hline
\end{tabular}

For complex $3 \mathrm{~K}_{\mathrm{app}}=1.53 \times 10^{4} \mathrm{M}^{-1}$ at $298 \mathrm{~K}$. 
Table 3

Binding constants for the interaction of the complexes 1, $\mathbf{2}$ and $\mathbf{3}$ with HSA.

\begin{tabular}{llll}
\hline & \multicolumn{3}{l}{$\mathbf{1 0}^{\mathbf{4}} \mathbf{K}\left(\mathbf{M}^{-\mathbf{1}}\right)$} \\
\cline { 2 - 4 } Temperature (K) & $\mathbf{1}$ & $\mathbf{2}$ & $\mathbf{3}$ \\
\hline 293 & $4.46 \pm 0.50$ & $5.35 \pm 0.31$ & $1.64 \pm 0.24$ \\
303 & $12.7 \pm 0.40$ & $7.81 \pm 0.23$ & $2.26 \pm 0.50$ \\
308 & $82.1 \pm 0.2$ & $12.7 \pm 0.06$ & $2.43 \pm 0.63$ \\
\hline
\end{tabular}




\section{Table 4}

Anti-proliferative activity of complexes 1-4 in panel of four human cancer cell lines.

\begin{tabular}{|c|c|c|c|c|}
\hline \multirow[b]{2}{*}{ Compound } & \multicolumn{4}{|l|}{$\mathrm{IC}_{50}(\mu \mathrm{M})$} \\
\hline & MDA-MB-231 & MCF-7 & HCT-116 & HT29 \\
\hline 1 & $12.3 \pm 0.4$ & $13.8 \pm 0.4$ & $15.3 \pm 2.1$ & $16.7 \pm 10.1$ \\
\hline 2 & $3.69 \pm 0.80$ & $3.86 \pm 0.96$ & $1.41 \pm 0.61$ & $5.22 \pm 1.08$ \\
\hline 3 & $3.72 \pm 2.12$ & $3.20 \pm 0.14$ & $2.10 \pm 0.53$ & $3.23 \pm 0.13$ \\
\hline 4 & $8.27 \pm 4.90$ & $12.8 \pm 0.53$ & $28.1 \pm 19.6$ & $11.8 \pm 0.4$ \\
\hline Cisplatin & 730 & $506 \pm 86$ & 3.10 & 24.3 \\
\hline
\end{tabular}

